\title{
Crystal Structure of 4'-Chlorobenzoylmethylenetriphenylphosphorane ylide, $\mathrm{C}_{26} \mathrm{H}_{20} \mathrm{ClOP}$
}

\author{
Seyyed Javad SabouncheI, ${ }^{* \dagger}$ Hassan Nemattalab, ${ }^{*}$ and Hamid Reza Khavasi** \\ * Faculty of Chemistry, Bu-Ali Sina University, Hamedan, 65174, Iran \\ **Department of Chemistry, Shahid Beheshti University, Evin, Tehran, 1983963113, Iran
}

\begin{abstract}
The crystal structure of a colorless phosphorus ylide, $\mathrm{Ph}_{3} \mathrm{PCHCOC}_{6} \mathrm{H}_{4} \mathrm{Cl}$, was determined by the X-ray diffraction method. All atoms occupy general positions in the monoclinic space group, $C 2 / c$, and have the following unit-cell dimensions: $a=16.6184(9) \AA, b=10.9196(6) \AA, c=23.5465(12) \AA, \beta=100.366(4)^{\circ}, Z=8$ and $V=4203.2(4) \AA^{3}$.
\end{abstract}

(Received September 22, 2009; Accepted December 4, 2009; Published on web May 10, 2010)

Phosphorus ylides are important reagents in organic chemistry, especially in the synthesis of naturally occurring products with biological and pharmacological activities. ${ }^{1}$ The chemistry of organic phosphorus compounds has shown remarkable growth throughout the past 5 decades. Meanwhile, it has attracted much interest, especially concerning extensive utilization of the organophosphorus derivatives as plasticizers for synthetics, extraction agents, oxidation inhibitors for lubricants, flotation agents, complexing agents for transition metals, and insecticides. ${ }^{2,3}$

Preparation: This compound was prepared according to a published method. ${ }^{4}$ Colorless crystals of $\mathrm{Ph}_{3} \mathrm{PCHCOC}_{6} \mathrm{H}_{4} \mathrm{Cl}$ (in Fig. 1) were obtained from a methanol solution by slow evaporation of the solvent.

Single crystal X-ray diffraction analysis was performed on a STOE IPDS-II two-circle diffractometer using graphitemonochromated Mo $K_{\alpha}$ X-ray radiation $(\lambda=0.71073 \AA)$. Data collection was performed at $120(2) \mathrm{K}$ using the $\omega$-scan technique and the STOE X-AREA software package. ${ }^{5}$ The crystal structure was solved by direct methods and refined by using the X-STEP32 crystallographic software package. ${ }^{6,7}$ All of the nonhydrogen atoms were refined anisotropically. All hydrogen atoms were located at ideal positions. Table 1 provides the crystallographic results and refinement information.

All hydrogen atoms were refined with the riding model to

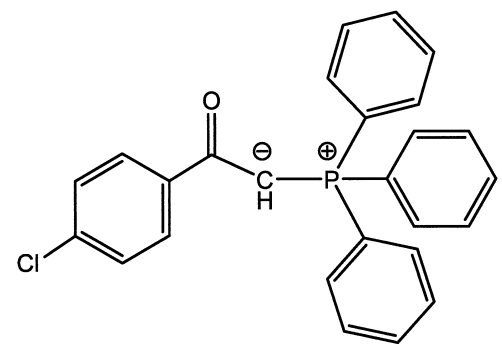

Fig. 1 Chemical structure.

† To whom correspondence should be addressed.

E-mail: jsabounchei@yahoo.co.uk final $R$ indices of $R_{1}(0.0377)$ and $W R_{2}(0.0989)$. Selected bond lengths and angles are given in Table 2.

Table 1 Crystal and experimental data

\begin{tabular}{|c|c|}
\hline Compound & $\mathrm{ClC}_{6} \mathrm{H}_{4} \mathrm{COCHPPh}_{3}$ \\
\hline Empirical formula & $\mathrm{C}_{26} \mathrm{H}_{20} \mathrm{ClOP}$ \\
\hline$F w$ & 414.84 \\
\hline Temperature (K) & $120(2)$ \\
\hline Wavelength $(\AA)$ & 0.71073 \\
\hline Crystal system & Monoclinic \\
\hline Space group & $C 2 / c$ \\
\hline$a(\AA)$ & $16.6184(9)$ \\
\hline$b(\AA)$ & $10.9196(6)$ \\
\hline$c(\AA)$ & $23.5465(12)$ \\
\hline$\alpha\left({ }^{\circ}\right)$ & 90 \\
\hline$\beta\left(^{\circ}\right)$ & $100.366(4)$ \\
\hline$\left.x^{\circ}\right)$ & 90 \\
\hline Volume $\left(\AA^{3}\right)$ & $4203.2(4)$ \\
\hline$Z$ & 8 \\
\hline$\Delta / \sigma$ & 0.011 \\
\hline$D_{\text {Calc }}\left(\mathrm{Mg} / \mathrm{m}^{3}\right)$ & 1.311 \\
\hline Absorption coefficient $\left(\mathrm{mm}^{-1}\right)$ & 0.273 \\
\hline$F\left(\begin{array}{lll}0 & 0 & 0\end{array}\right)$ & 1728 \\
\hline Crystal size (mm) & $0.50 \times 0.16 \times 0.12$ \\
\hline$\theta$ range for data collection $\left({ }^{\circ}\right)$ & 2.24 to 29.19 \\
\hline Limiting indices & $\begin{array}{l}-22 \leqslant h \leqslant 22,-14 \leqslant k \leqslant 14, \\
-23 \leqslant l \leqslant 32\end{array}$ \\
\hline $\begin{array}{l}\text { Reflections collected/unique } \\
\left(R_{\text {int }}\right)\end{array}$ & $15184 / 5571(0.0388)$ \\
\hline Completeness to $\theta$ & $97.9 \%$ \\
\hline Absorption correction & Numerical \\
\hline $\begin{array}{l}\text { Maximum and minimum } \\
\text { transmission }\end{array}$ & 0.970 and 0.020 \\
\hline Refinement method & Full-matrix least-squares on $F^{2}$ \\
\hline Data/restraints/parameters & $5571 / 0 / 262$ \\
\hline Goodness-of-fit on $F^{2}$ & 1.088 \\
\hline Final $R$ indices $[I>2 \sigma(I)]$ & $R_{1}=0.0377, w R_{2}=0.0989$ \\
\hline$R$ indices (all data) & $R_{1}=0.0400, w R_{2}=0.1005$ \\
\hline $\begin{array}{l}\text { Largest difference in peak and } \\
\text { hole }\left(e \AA^{-3}\right)\end{array}$ & 0.405 and -0.412 \\
\hline $\begin{array}{l}\text { Crystal data have been } \\
\text { Crystallographic Data Center ur }\end{array}$ & $\begin{array}{l}\text { posited at the Cambridge } \\
\text { r the number CCDC } 648308 \text {. }\end{array}$ \\
\hline
\end{tabular}




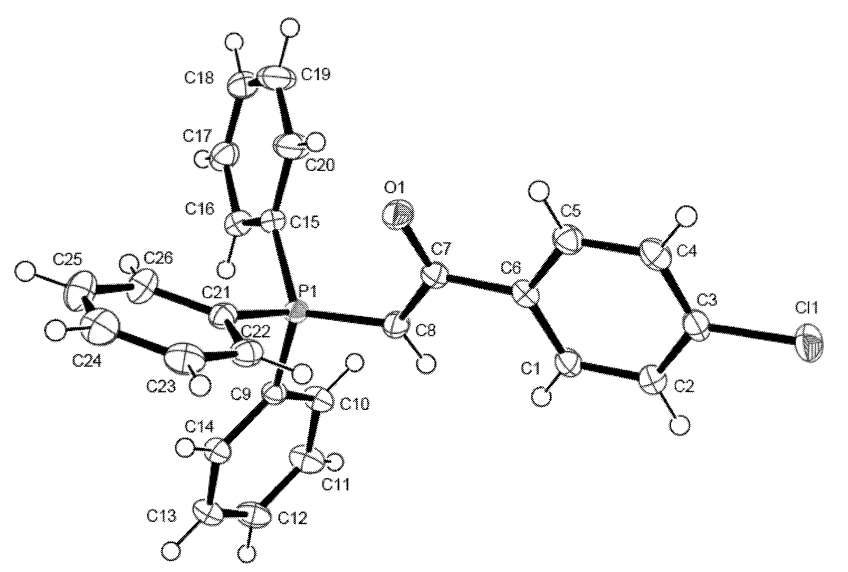

Fig. 2 ORTEP drawing, showing the atom-numbering scheme.

An ORTEP plot (Fig. 2) shows that in the molecule of the title compound, 4'-chlorobenzoylmethylenetriphenylphosphorane ylide, $\mathrm{C}_{26} \mathrm{H}_{20} \mathrm{ClOP}$, the geometry around the $\mathrm{P}$ atom is nearly tetrahedral, and the $\mathrm{O}$ atom is oriented cis to the $\mathrm{P}$ atom. The chlorophenyl ring of the benzoyl group is twisted with respect to the plane of the carbonyl group through an angle of $-3.99(18)^{\circ}$. The $\mathrm{P}-\mathrm{C}(8)$ (1.7198(13)) and $\mathrm{C}(8)-\mathrm{C}\left(7, \mathrm{sp}^{2}\right)(1.4031(16))$ bond lengths are shorter than the $\left(\mathrm{P}^{+}-\mathrm{C}\left(\mathrm{sp}^{3}\right)(1.800)\right.$ and $(1.511)$ normal values, respectively. This is due to the ylidic resonanace and intermediate between common values for single and double bonds (for example $\mathrm{P}-\mathrm{C}=1.80$ and $\mathrm{P}=\mathrm{C}=1.66 \AA$ ). The $\mathrm{CO}$ bond also is longer (1.2580) (15) than the normal value (1.210). This bond distance suggests resonance delocalization in these molecules (scheme 1).
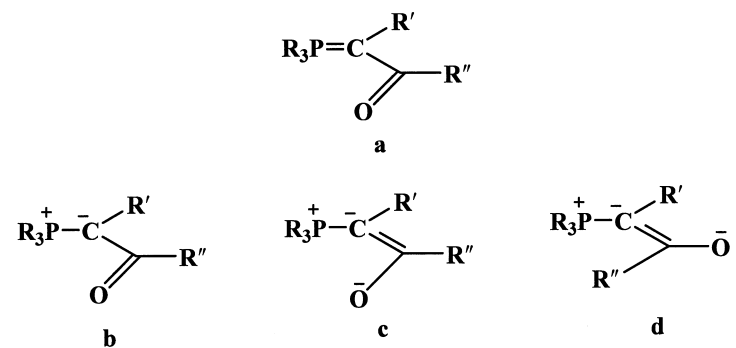

Scheme (1)

\section{Acknowledgments}

We are grateful to Bu-Ali-Sina and Shahid Beheshti University for financial support.

Scheme (1)
Table 2 Selected key bond lengths $(\AA)$, bond angles $\left({ }^{\circ}\right)$ and torsion angles $\left({ }^{\circ}\right)$

$\begin{array}{ll}\mathrm{C}(7)-\mathrm{O}(1) & 1.2580(15) \\ \mathrm{C}(7)-\mathrm{C}(8) & 1.4031(16) \\ \mathrm{C}(6)-\mathrm{C}(7) & 1.5110(16) \\ \mathrm{C}(8)-\mathrm{P}(1) & 1.7198(13) \\ \mathrm{C}(8)-\mathrm{H}(8) & 0.9300 \\ \mathrm{C}(9)-\mathrm{P}(1) & 1.8037(12) \\ \mathrm{C}(15)-\mathrm{P}(1) & 1.8177(12) \\ \mathrm{C}(21)-\mathrm{P}(1) & 1.8097(13) \\ \text { Bond angles } & \\ \mathrm{O}(1)-\mathrm{C}(7)-\mathrm{C}(8) & 123.04(11) \\ \mathrm{O}(1)-\mathrm{C}(7)-\mathrm{C}(6) & 118.03(11) \\ \mathrm{C}(8)-\mathrm{C}(7)-\mathrm{C}(6) & 118.91(11) \\ \mathrm{C}(7)-\mathrm{C}(8)-\mathrm{P}(1) & 120.51(9) \\ \mathrm{C}(7)-\mathrm{C}(8)-\mathrm{H}(8) & 119.7 \\ \mathrm{P}(1)-\mathrm{C}(8)-\mathrm{H}(8) & 119.7 \\ \mathrm{C}(8)-\mathrm{P}(1)-\mathrm{C}(9) & 105.03(6) \\ \mathrm{C}(8)-\mathrm{P}(1)-\mathrm{C}(21) & 114.26(6) \\ \mathrm{C}(9)-\mathrm{P}(1)-\mathrm{C}(21) & 107.84(5) \\ \mathrm{C}(8)-\mathrm{P}(1)-\mathrm{C}(15) & 116.07(6) \\ \mathrm{C}(9)-\mathrm{P}(1)-\mathrm{C}(15) & 108.13(6) \\ \mathrm{C}(21)-\mathrm{P}(1)-\mathrm{C}(15) & 105.18(6) \\ \text { Torsion angles } & \\ \mathrm{O}(1)-\mathrm{C}(7)-\mathrm{C}(8)-\mathrm{P}(1) & -3.98(18) \\ \mathrm{C}(1)-\mathrm{C}(6)-\mathrm{C}(7)-\mathrm{C}(8) & -4.42(18) \\ \mathrm{C}(1)-\mathrm{C}(6)-\mathrm{C}(7)-\mathrm{O}(1) & 173.84(12) \\ \mathrm{C}(5)-\mathrm{C}(6)-\mathrm{C}(7)-\mathrm{O}(1) & -3.69(17)\end{array}$

\section{References}

1. G. Wittig, Science, 1980, 210, 600 .

2. A. W. Johnson, "Ylides and Imines of Phosphorus", John Wiley, New York, 1993.

3. H. Schmidbaur, Angew. Chem. Int. Ed. Engl., 1983, 22, 907.

4. H. J. Bestmann and B. Arnason, Chem. Ber., 1962, 95, 1513.

5. Stoe \& Cie, X-AREA, version 1.30: Program for the acquisition and analysis of data; Stoe \& Cie $\mathrm{GmbH}$ : Darmatadt, Germany, 2005.

6. G. M. Sheldrick, SHELX97. Program for crystal structure solution and refinement, University of Göttingen, Germany 1997.

7. Stoe \& Cie, X-STEP32, Version 1.07b: Crystallographic package; Stoe \& Cie GmbH: Darmstadt, Germany, 2000. 